\title{
Extraction, Characterization, Antioxidant and Anti-Inflammatory Properties of Carotenoids from the Shell Waste of Arabian Red Shrimp Aristeus alcocki, Ramadan 1938
}

\author{
S. Sindhu ${ }^{a}$ and P.M. Sherief*,b \\ ${ }^{a}$ Department of Processing Technology, College of Fisheries, Panangad. P.O, Kochi 682 506, Kerala, India \\ ${ }^{b}$ Department of Processing Technology, College of Fisheries, Panangad. P.O, Kochi 682 506, Kerala, India
}

\begin{abstract}
Shrimp processing waste is the single largest industrial waste in India causing diverse environmental problems. Extraction of carotenoids from the shell waste of the Arabian red shrimp Aristeus alcocki was investigated using different organic solvents, and vegetable oils, under wet and dry conditions, with and without deproteinization. The highest carotenoid yield was obtained with non-deproteinized wet waste extracted using acetone. The carotenoid yield was found to be double that of Pandalus borealis shell waste, which is currently used as one of the commercial sources of natural astaxanthin. Thin Layer Chromatography (TLC) analysis of the carotenoid extract showed that it contains free astaxanthin, astaxanthin monoester and astaxanthin diester in the ratio 1:1:2. gas chromatography (GC) analysis of the fatty acids esterified with astaxanthin revealed that saturated fatty acids, monounsaturated fatty acids and poly unsaturated fatty acids (PUFAs) are in the ratio 5:3:2 in monoester, whereas in diester they are in the ratio 4:3:3. The main fatty acids in monoester and diester are palmitic acid, oleic acid, stearic acid and $\omega-3$ PUFAs: docosahexaenoic acid (DHA) and eicosapentaenoic acid (EPA). The in vitro antioxidant activity of the carotenoid extract showed significant hydroxyl radical scavenging activity, superoxide anion scavenging activity and inhibition of lipid peroxidation at nanogram levels. The carotenoid extract significantly reduced carageenan induced paw edema in mice, percentage inhibition being 47.83 and 67.11 percent at astaxanthin concentrations of $0.5 \mathrm{mg} / \mathrm{kg}$ body weight and $1.0 \mathrm{mg} / \mathrm{kg}$ body weight, respectively. The inhibition of inflammation at $1.0 \mathrm{mg} / \mathrm{kg}$ body weight was greater than that produced by the standard reference drug diclofenac. The strong antioxidant and anti-inflammatory activities exhibited by the carotenoid extract of the shrimp shell might be due to the combined action of astaxanthin and $\omega-3$ PUFAs present in the astaxanthin esters.
\end{abstract}

Keywords: Anti-inflammatory, Antioxidant, Aristeus alcocki ,Astaxanthin, carotenoids, shell waste.

\section{INTRODUCTION}

Shrimp processing is one of the major food industries in India. Shrimp processing waste is the single largest industrial fish waste in the country causing diverse environmental problems. Only $40 \%$ of the shrimp is edible and remaining $60 \%$ account for the processing discards [1]. These discards find very little practical application at present and are categorized as a major environmental contaminant. Effective utilization of the waste can resolve many of the environmental concerns facing the shellfish processors [2]. In addition to the traditional uses, shrimp waste is one of the important natural sources of carotenoid [3-4]. Shrimp discards could be the cheapest raw material for carotenoid recovery, and later could be a better alternative to synthetic carotenoid [5]. The major component of carotenoids of shrimp and crab shell backs were mono and diesters of astaxanthin [2] a very potent antioxidant with some unique properties suitable for use as a drug or food supplement. Effective utilization of shrimp shell waste will enhance its status as a biomedical research material, for development of natural medicine without side effects.

*Address correspondence to this author at the Department of Processing Technology, College of Fisheries, Panangad. P.O, Kochi 682 506, Kerala, India; Tel: +91 484 2700274; Fax: +91 484 2700337;

E-mail: pmsherief@gmail.com
Several organic solvent systems were reported as extraction solvent for the extraction of carotenoids from different crustacean shell discards. Sachindra et al. [6] has patented a method for extraction of carotenoids from shrimp waste using solvent mixtures acetone \& hexane and isopropyl alcohol \& hexane. Sachindra et al., [7] studied the extractability of shrimp waste carotenoids using different organic solvents and solvent mixtures to optimize the extraction conditions for maximum yield. Organic solvents such as acetone, ethanol, hexane can be used for the extraction of carotenoids [8-12]. Methods are available for extraction of carotenoids from crustacean wastes using vegetable oils [13-20].

The present study is aimed at complete utilization of shrimp waste or to "value add" the same. The novel extraction techniques raise the possibility of not only accessing a new source of astaxanthin but also finding an environmentally friendly use of thousands of tonnes of prawn waste discarded by seafood lovers around the world each year. The effect of deproteinization on extraction yield of carotenoids is also investigated in this study. The residue available after extraction of carotenoids can be used for production of chitin and chitosan, thus having an integrated approach for efficient utilization of shrimp waste [21]. Thus the generation of dual income from this cheap raw material will lead to a profitable waste utilization strategy without causing 
environmental pollution. The in vitro antioxidant property and anti-inflammatory activity of shrimp shell astaxanthin were also studied.

\section{MATERIALS AND METHODS}

\subsection{Preparation of Raw Material}

Shell waste from the deep sea shrimp Aristeus alcocki was collected from the processing plants: RF Exports Pvt. Ltd, Chandiroor and Caps Seafoods Pvt. Ltd, Vypeen, Kerala, India. The waste was transported to the laboratory in an insulated box in iced condition. Aristeus alcocki is processed as headless (HL) and peeled undeveined (PUD), the major product styles marketed under the trade name "red ring". The product styles generate waste such as cephalothorax, abdominal shell and tail portion. Adhering meat from the cephalothorax was removed and the waste was washed under running water and dried under shade. They were packed in polyethylene bags and stored at $-20^{\circ} \mathrm{C}$ until use. A second lot was stored wet, after removing the adhering meat, was packed in polythene covers and stored at $-20^{\circ} \mathrm{C}$. Both wet and dry samples were homogenized in a laboratory mixer (Crompton Greaves, India) prior to extraction of carotenoids and estimation of different components such as protein, chitin, lipids and ash in the shell.

\subsection{Proximate Composition}

Moisture, ash, total nitrogen and total lipids were quantified according to [22]. Chitin was determined according to the method of Spinelli et al., [23]. Briefly, samples were extracted with $2 \% \mathrm{NaOH}(\mathrm{w} / \mathrm{v})$ followed by demineralization with $5 \% \mathrm{HCl}$. The total protein content of the waste was calculated by subtracting the chitin nitrogen [24] from the total nitrogen, then using a conversion factor of 6.25. All analyses were completed in triplicate. All the chemicals used in the various tests were of either analar or guaranteed reagent.

\subsection{Deproteinization of Shrimp Shell Waste}

Alkali deproteinization of shell waste was carried out according to the method of Shahidi and Synowiecki [25]. Enzymatic deproteinization of shrimp waste was carried out using enzyme pancraetin (from pig pancreas, Merck India Ltd, Mumbai) according to the modified method of [19]. The deproteinized residue was dried and total nitrogen of the supernatant was determined by Microkjeldahl's method [22]. Protein content was calculated. Percentage of deproteinization was calculated using the formula

$$
\% \text { Deproteinization }=\frac{\text { Protein in supernatant }}{\text { Protein in waste }} \times 100
$$

\subsection{Extraction of Astaxanthin from Shrimp Shell Waste}

Extraction of astaxanthin from shrimp shell waste was investigated by application of the methods of Barbosa et al. [26], Chen and Meyers, [15], Sachindra et al. [7], Kobayashi et al. [27] and Sachindra and Mahendrakar [18] using different organic solvents and vegetable oils. Homogenized shrimp waste was extracted using four different organic solvents [acetone, ether: acetone:water 15:75:10 (v/v/v), hexane:isopropanol 3:2 (v/v), 90\% acetone) and three different vegetable oils, (coconut oil, sunflower oil, soyabean oil) with and without deproteinization. Waste was subjected to deproteinization using alkali and enzyme as described in section 2.3.

A known weight of homogenized wet and dry shrimp shell waste $(1 \mathrm{~g})$ was extracted with $10 \mathrm{ml}$ of solvent in order to assess astaxanthin recovery. The carotenoid extract was filtered using Whatman No.42 filter paper. Recovered shrimp waste was repeatedly extracted with fresh solvent until the filtrare was colourless, to a maximum of three times. The pooled extract was collected for the quantification of astaxanthin. In the case of acetone extraction the pooled extract was collected in a separating funnel, $12.5 \mathrm{ml}$ of petroleum ether $\left(\mathrm{BP} 40-60^{\circ} \mathrm{C}\right)$ and $9.4 \mathrm{ml}$ of $0.73 \%(\mathrm{w} / \mathrm{v})$ $\mathrm{NaCl}$ solution were added. After thorough mixing the epiphase was collected. To the lower phase an equal volume of water was added, mixed and the epiphase was collected, the pooled epiphase was evaporated to dryness under a stream of nitrogen. The pooled extract in the case of hexane:isopropanol $(3: 2, \mathrm{v} / \mathrm{v})$ extraction was phase separated with equal volume of $1 \%(\mathrm{w} / \mathrm{v}) \mathrm{NaCl}$ solution. The epiphase was collected and dehydrated with anhydrous sodium sulphate, and then evaporated to dryness under vacuum and the residue was dissolved in a $5 \mathrm{ml}$ of hexane. In other cases the solvent was removed under vacuum and redissolved in 5 $\mathrm{ml}$ of hexane. The ratio of oil: waste used in vegetable oil extraction was 2:1 for wet sample and 4:1 for dry samples. An antioxidant butyl hydroxy toluene (BHT) was added at $0.05 \%(\mathrm{w} / \mathrm{v})$ and heated at $70^{\circ} \mathrm{C}$ for $150 \mathrm{~min}$, centrifuged and the pigmented oil was recovered.

\subsection{Quantification of Astaxanthin}

The organic solvent extracted astaxanthin was quantified by measuring absorbance at $470 \mathrm{~nm}$ and using the equation of Kelley and Harmon [28].

$$
\operatorname{AST}(\mu g / g)=\frac{A \times D \times 10^{6}}{100 \times G \times d \times E_{1 \mathrm{~cm}}^{1 \%}}
$$

Where AST is astaxanthin concentration in $\mu \mathrm{g} / \mathrm{g}$, A is absorbance, $\mathrm{D}$ is volume of extract in hexane, $10^{6}$ is dilution multiple, $G$ is weight of sample in $g, d$ is cuvette width $(1 \mathrm{~cm})$ and $\mathrm{E}$ is extinction co-efficient, 2100.

For samples extracted in oil, quantification was done by measuring absorbance at $485 \mathrm{~nm}$ and using an extinction coefficient of 2155 in the above equation.

\subsection{Identification of Different Components in Shrimp Shell Waste Extract by thin Layer Chromatography (TLC)}

Analysis of different components in the shrimp shell extract was done using thin layer chromatography (TLC) based on the method of Kobayashi and Sakamoto [29]. For this, a small volume of the extract was spotted on silicagel $G$ plate and developed using acetone: hexane 3:7 (v/v). The separated bands were identified using standard astaxanthin (Source: Green algae; Manufacturer: Sigma Chemicals, USA) and internationally accepted $R_{f}$ values for astaxanthin monoester and astaxanthin diester. The different fractions, astaxanthin, astaxanthin monoester, astaxanthin diester were quantified by scraping out the respective bands in TLC plate. The astaxanthin present in the scraped out sample was 
redissolved in $5 \mathrm{ml}$ of hexane and quantified as described earlier (2.5).

\subsection{Analysis of Fatty Acids in Astaxanthin Monoester} and Astaxanthin Diester by Gas Liquid Chromatography

\subsubsection{Saponification}

The astaxanthin monoester and diester fractions separated in TLC were redissolved in $2 \mathrm{ml}$ of acetone and the extract was transferred to a round bottom flask. Acetone was evaporated under nitrogen. Added $10 \mathrm{ml}$ of methanol and $1 \mathrm{ml}$ of $40 \% \mathrm{NaOH}$ and the flask was connected to an air condenser, refluxed with nitrogen. The sample was saponified by boiling for 30 minutes. After cooling the unsaponifiable matter was removed by the addition of $10 \mathrm{ml}$ of petroleum ether (B.P $60^{\circ} \mathrm{C}-80^{\circ} \mathrm{C}$ ). The aqueous layer was acidified with $1 \mathrm{ml}$ of concentrated hydrochloric acid $(98 \%$ $\mathrm{HCl}$ ). Free fatty acid (FFA) was extracted with $5 \mathrm{ml}$ of petroleum ether $\left(\mathrm{BP} 40^{\circ} \mathrm{C}-60^{\circ} \mathrm{C}\right)$ and dried under anhydrous sodium sulphate.

\subsubsection{Gas Chromatography (GC)}

The free fatty acids obtained from above were quantitatively converted to fatty acid methyl esters (FAME) using Boron triflouride-methanol reagent by the method of Metcalfe et al. [30]. A known volume of the free fatty acid extract in petroleum ether $(5 \mathrm{ml})$ was taken in a round bottom flask and evaporated completely under nitrogen and $5 \mathrm{ml}$ of $0.5 \mathrm{~N}$ methanolic $\mathrm{NaOH}$ was added. This mixture was refluxed under water condenser (Borosil,India) for 5-10 $\mathrm{min}$ under a nitrogen atmosphere. $6 \mathrm{ml}$ of boron trifluoride methanol $\left(\mathrm{BF} 3-\mathrm{CH}_{3} \mathrm{OH}\right)$ solution was added using a glass pipette through the condenser and continued boiling for 2 min. The flask was removed and cooled to warmness and 6 $\mathrm{ml}$ of fully saturated $\mathrm{NaCl}$ solution was added. The stoppered flask was shaken vigourously for $15 \mathrm{~min}$ and the upper phase was collected. The aqueous phase was extracted with further two $30 \mathrm{ml}$ portions of the petroleum ether (B.P. $60-80^{\circ} \mathrm{C}$ ). The combined extract was washed with three 20 $\mathrm{ml}$ portions of water, dried over anhydrous $\mathrm{Na}_{2} \mathrm{SO} 4$, filtered through Whatman No.1 filter paper and evaporated using a flash evaporator (BUCHI, Labortechnik AG, Flawil) under a stream of nitrogen. Methyl esters of fatty acids were taken in $5 \mathrm{ml}$ of hexane and were separated by gas chromatography (Trace GC Ultra, Thermo Electron Corporation) equipped with Elite 225 (Perkin Elmer) capillary column and a flame ionization detector in the presence of hydrogen and air. Nitrogen at a flow rate $0.5 \mathrm{ml} / \mathrm{min}$ was the carrier gas. Other $\mathrm{GC}$ conditions were: injector temperature - $250^{\circ} \mathrm{C}$; temperature programme $-110^{\circ} \mathrm{C}-4 \mathrm{~min} 2.7^{\circ} \mathrm{C} / \mathrm{min}-240^{\circ} \mathrm{C}-$ $5 \mathrm{~min}$; Detector at $275^{\circ} \mathrm{C}$. The fatty acids were identified and quantified by external standard method using the fatty acid standard mixture purchased from M/s. Suppleco. The output of the GC was integrated using Thermocard software (Thermo Electron Corporation, Italy) and individual fatty acids were expressed as per cent

\subsection{Assay of Antioxidant Activity}

\subsubsection{Superoxide Anion Scavenging Activity}

Superoxide anion $\left(\mathrm{O}_{2}{ }^{-}\right)$generated from the photo reduction of riboflavin was detected by nitroblue tetrazolium (NBT) reduction method of McCord and Fridovich [31]. The reaction mixture contained $6 \mathrm{mM}$ ethylenediaminetetraacetic acid (EDTA) containing $3 \mu \mathrm{g} \mathrm{NaCN} ; 2 \mu \mathrm{M}$ riboflavin; $50 \mu \mathrm{M}$ NBT; $67 \mathrm{mM} \mathrm{KH}_{2} \mathrm{PO}_{4}-\mathrm{Na}_{2} \mathrm{HPO}_{4}$ buffer, $(\mathrm{pH} 7.8)$ and various concentrations of astaxanthin $(5 \mathrm{ng} / \mathrm{ml}$ to $50 \mathrm{ng} / \mathrm{ml})$ in a final volume of $3 \mathrm{ml}$. The tubes were illuminated under incandescent lamp for $15 \mathrm{~min}$. The optical density (OD) at $530 \mathrm{~nm}$ was measured using UV/VIS Spectrophotometer (Model V-530, Jasco make, Japan) before and after illumination. The inhibition of superoxide radical was determined by comparing the absorbance values of the control with that of treatments. Quercetin (Sigma Chemicals, USA )was used as standard.

$$
\% \text { inhibition }=\frac{\text { OD of control }- \text { OD of test X } 100}{\text { OD of control }}
$$

\subsubsection{Inhibition of Lipid Peroxidation}

The lipid peroxidation induced by $\mathrm{Fe}^{2+}$ - ascorbate system in beef liver homogenate was estimated by thiobarbituric acid reaction method of Ohkawa et al. [32]. The reaction mixture contained $0.1 \mathrm{ml}$ of beef liver homogenate $(25 \% \mathrm{w} / \mathrm{v})$ in Tris- $\mathrm{HCl}$ buffer $(20 \mathrm{mM}, \mathrm{pH} 7.0)$; $30 \mathrm{mM} \mathrm{KCl} ; 0.16 \mathrm{mM} \mathrm{FeSO}{ }_{4}\left(\mathrm{NH}_{4}\right)_{2} \mathrm{SO}_{4} .6 \mathrm{H}_{2} \mathrm{O} ; 0.06 \mathrm{mM}$ ascorbate and various concentrations of astaxanthin $(5 \mathrm{ng} / \mathrm{ml}$ to $50 \mathrm{ng} / \mathrm{ml}$ ) in a final volume of $0.5 \mathrm{ml}$. The reaction mixture was incubated at $37^{\circ} \mathrm{C}$ for $1 \mathrm{~h}$. After the incubation period, $0.4 \mathrm{ml}$ was removed and treated with $0.2 \mathrm{ml}$ of sodium dodecyl sulphate (SDS) $(8.1 \%) ; 1.5 \mathrm{ml}$ of $0.8 \%$ thiobarbituric acid and $1.5 \mathrm{ml}$ of $20 \%$ acetic acid (pH 3.5). The total volume was made up to $4 \mathrm{ml}$ with distilled water and then kept in a water bath at $95-100^{\circ} \mathrm{C}$ for $1 \mathrm{~h}$. After cooling $1 \mathrm{ml}$ of distilled water and $5.0 \mathrm{ml}$ of n-butanol and pyridine mixture $(15: 1, \mathrm{v} / \mathrm{v})$ were added to the reaction mixture, shaken vigourously in an electric cyclomixer and centrifuged at $4000 \mathrm{rpm}$ for $10 \mathrm{~min}$. The butanol-pyridine layer was removed and absorbance at $532 \mathrm{~nm}$ was measured using UV/VIS Spectrophotometer, , (Model V-530, Jasco make, Japan). Inhibition of lipid peroxidation was determined by comparing the OD of treatment with that of control. Catechin (Sigma Chemicals, USA) was used as the standard at a concentration ranging from $100 \mu \mathrm{g} / \mathrm{ml}$ to $1000 \mu \mathrm{g} / \mathrm{ml}$.

\subsubsection{Hydroxyl Radical Scavenging Activity}

Hydroxyl free radicals degrade 2-deoxy ribose to form thiobarbituric acid reactive substances (TBARS) [33]. Hydroxyl radical scavenging activity was determined by studying the competition between deoxyribose and the astaxanthin extract for the hydroxyl radical generated from $\mathrm{Fe}^{2+}$-ascorbate-EDTA- $\mathrm{H}_{2} \mathrm{O}_{2}$ system (Fenton's reaction). The reaction mixture contained $2.8 \mathrm{mM}$ deoxyribose; $0.1 \mathrm{mM}$ $\mathrm{FeCl}_{3} ; 20 \mathrm{mM} \mathrm{KH} \mathrm{PO}_{4}-\mathrm{KOH}$ buffer $(\mathrm{pH} 7.4) ; 0.1 \mathrm{mM}$ EDTA; $1.0 \mathrm{mM} \mathrm{H} \mathrm{H}_{2} ; 0.1 \mathrm{mM}$ ascorbic acid and various concentrations of astaxanthin $(10 \mathrm{ng} / \mathrm{ml}$ to $100 \mathrm{ng} / \mathrm{ml})$ in a final volume of $1 \mathrm{ml}$. The TBARS formed was estimated by reaction with thiobarbituric acid (TBA) to form pink coloured complex [32]. The hydroxyl radical scavenging activity was determined by comparing absorbance of control with that of treatments at $532 \mathrm{~nm}$. Catechin (Sigma Chemicals, USA)was used as standard at a concentration ranging from $100 \mu \mathrm{g} / \mathrm{ml}$ to $1000 \mu \mathrm{g} / \mathrm{ml}$. 


\subsection{Assay of Antiinflammatory Activity}

\subsubsection{Animals}

Antiinflammatory activity of astaxanthin was studied using male Balb/c mice. Male Balb/c mice weighing 20-25 g body weight, purchased from Small Animal Breeding Centre, Kerala Agricultural University (KAU), Thrissur. The animals were housed under hygienic conditions in polypropylene cages under 12 hour light and dark cycle. All procedures involving animal care and experiments were in accordance with the guidelines of Committee for the Purpose of Control and Supervision of Experiments on Animals (CPCSEA), New Delhi, India and with the approval of Institutional Animal Ethics Committee (IAEC).

\subsubsection{Carrageenan Induced Paw Edema}

Carrageenan induced paw edema was used for determining the acute anti-inflammatory activity of astaxanthin. Animals were divided into four groups containing six animals in each group. In all the groups, inflammation was produced by injecting $0.025 \mathrm{ml}$ of a $1 \%$ (w./v) freshly prepared carrageenan (Source: Irish moss; Manufacturer: Central Drug House, New Delhi) solution in the right hind paw of the mice. One group with carrageenan alone served as positive control. The second and third groups were administered with astaxanthin extract at a concentration of $0.5 \mathrm{mg} / \mathrm{Kg}$ and $1.0 \mathrm{mg} / \mathrm{Kg}$ body weight intraperitoneally one hour prior to carrageenan injection. The fourth group was administered with a standard reference drug diclofenac (Sigma Chemicals, USA) $10 \mathrm{mg} / \mathrm{Kg}$ intraperitoneally. The paw thickness was measured using vernier calipers before and $3 \mathrm{~h}$ after carrageenan injection [34].

Increase in paw thickness was calculated using the formula $P_{t}-P_{o}$, where $P_{t}$ is the thickness of paw at time ' $t$ ' (i.e. $3 \mathrm{~h}$ after carrageenan injection) and $P_{o}$ is the paw thickness at ' 0 ' time. Percentage inhibition was calculated using the formula $(1-\mathrm{T} / \mathrm{C}) \times 100$ where $\mathrm{C}$ is the increase in paw thickness of the control and $\mathrm{T}$ is that of the treatments.

\subsection{Statistical Analysis}

The statistical analyses of all the experiments were done using the statistical package SPSS 15 for windows. The analysis of variance technique was used to determine the significant difference between different treatments at $5 \%$ level of significance. Experimental data were expressed as mean \pm SD.

\section{RESULTS AND DISCUSSION}

\subsection{Proximate Composition of Shrimp Shell Waste}

The proximate composition of fresh and dried shrimp shell waste are presented in Table $\mathbf{1}$. The major components in shrimp shell waste are protein, ash and chitin. Proximate composition of shrimp shell waste varies with species and many other factors. Nair et al. [35] reported proximate composition of prawn waste as 75-80\% moisture, 30-35\% ash (dry basis), 35-40\% protein (dry basis), 15-20\% chitin (dry basis) and 3-5 \% fat (dry basis). The values observed in the present study also correlates with the above values, and also with the values reported by Madhavan and Nair [36].

Table 1. Proximate Composition of Shrimp Shell Waste of Aristeus alcocki, Ramadan, 1938 in Fresh and Dried Conditions, Per Cent by Weight $(n=3)$

\begin{tabular}{|c|c|c|}
\hline Components & Fresh $($ Mean \pm SD) & Dried (Mean \pm SD) \\
\hline \hline Moisture & $70.74 \pm 0.56$ & $14.57 \pm 0.16$ \\
\hline Ash & $10.36 \pm 1.13$ & $29.40 \pm 0.69$ \\
\hline Chitin & $9.80 \pm 0.53$ & $23.80 \pm 0.80$ \\
\hline Lipid & $1.03 \pm 0.11$ & $2.06 \pm 0.02$ \\
\hline Protein & $5.40 \pm 0.28$ & $29.71 \pm 0.85$ \\
\hline
\end{tabular}

\subsection{Deproteinisation of Shrimp Shell Waste}

Deproteinisation of shell waste using alkali $(\mathrm{KOH})$ and enzyme (Pancreatin) was carried out. Alkali deproteinsation was more efficient than enzyme deproteinisation. Per cent deproteinisation obtained with alkali and enzyme pancreatin are presented in Table 2. Holanda and Netto [19] reported that astaxanthin recovery from shrimp waste was enhanced with enzymatic hydrolysis of shrimp shell waste. This contradicts the result of the present study which showed that deproteinisation by enzyme or alkali decreases the extraction yield of carotenoids from shrimp shell waste. In this study, it was observed that when hydrolyzed astaxanthin leached into the medium, decreasing the carotenoid content of the residual shrimp waste.

\subsection{Extraction of Carotenoids From Shrimp Shell Waste}

The raw material used for the present study was shrimp shell wastes of deep sea shrimp Aristeus alcocki commonly called as Scarlet shrimp or Arabian red shrimp. To ensure maximum yield of carotenoid pigments this deep sea species was selected. The carotenoid astaxanthin was quantified in the shrimp shell extract of Aristeus alcocki in the present study at $470 \mathrm{~nm}$ in hexane. Cianci et al. [37] has reported that astaxanthin has a typical absorption maxima at $472 \mathrm{~nm}$ in hexane. The total carotenoids extracted from shrimp waste of Xiphopenaeus kroyeri were refered as astaxanthin by Holanda and Netto, [19].

Analysis of variance (Table 3) for extraction yields of carotenoids in different extraction media, with different samples demonstrated that the yield of carotenoids varied significantly between extraction solvents, between wet and dry samples and between deproteinised and non

Table 2. Extent of Deproteinisation of Aristeus alcockii Shrimp Waste Using Enzyme and Alkali, Percentage of Total Protein n=3

\begin{tabular}{|c|c|c|}
\hline Samples & Alkali deproteinization $(\%)($ Mean \pm SD) & Enzyme deproteinization $(\%)($ Mean \pm SD) \\
\hline \hline Wet & $77.68 \pm 0.31$ & $66.61 \pm 0.21$ \\
\hline Dry & $51.53 \pm 0.25$ & $35.34 \pm 0.04$ \\
\hline
\end{tabular}


Table 3. ANOVA for Extraction Yields of Carotenoids for Different Samples and Different Extraction Media

\begin{tabular}{|c|c|c|c|c|}
\hline Source of variation & Sum of squares & Degrees of freedom & Mean sum of squares & F-value \\
\hline \hline Samples & 35309.32 & 5 & 7061.86 & $6035.25^{*}$ \\
\hline Extraction medium & 8054.48 & 6 & 442.41 & $1147.26^{*}$ \\
\hline Interaction & 13206.78 & 30 & 1.170 & $376.22^{*}$ \\
\hline Error & 147.43 & 126 & & \\
\hline Total & 56718.01 & 167 & & \\
\hline
\end{tabular}

*Significant at $5 \%$ level Critical difference:0.284.

deproteinised samples. The mean extraction yields of carotenoids from shrimp shell waste with and without deproteinisation in dry and wet condition are presented in Table 4. The highest carotenoid yield of $87.14 \pm 4.55 \mu \mathrm{g} / \mathrm{g}$ was obtained with wet non deproteinised waste using acetone. Sachindra et al. [7] reported that a 50:50 mixture of isopropyl alcohol and hexane gave the highest yield $(43.91 \mu \mathrm{g} / \mathrm{g}$ wet waste) of carotenoid compared to acetone $(40.60 \mu \mathrm{g} / \mathrm{g}$ wet waste). On the contrary in the present study highest carotenoid yield was obtained with acetone (87.14 $\mu \mathrm{g} / \mathrm{g})$, when compared to $60: 40$ solution of hexane : isopropanol that yielded $(70.27 \mu \mathrm{g} / \mathrm{g})$. This difference may be due to difference in species or due to high polarity of acetone. Vimla and Paul [38] have reported that maximum yield of carotenoids from Penaeus monodon waste was obtained with acetone, compared to other solvents used for extraction. Polar solvents are generally a good extraction media for xanthophylls whereas non polar solvents are not recommended as their penetration through the hydrophobic mass that surrounds the pigment is limited [39].

The carotenoid yields from dry samples were significantly reduced compared to that of wet samples. On drying the shell colour was found to be bleached and the yield of astaxanthin was found to be very low from dried samples. Similarly the carotenoid yields from deproteinised samples were significantly lower than those of non deproteinised samples. Oil extraction of carotenoids was carried out using coconut oil, soybean and sunflower oil. Although carotenoid yield was significantly lower when oil was used as the extraction medium, of the three oils, coconut oil gave the highest yield $(3.32 \pm 0.23 \mu \mathrm{g} / \mathrm{g})$. Holanda and Netto [19] reported that astaxanthin recovery from shrimp waste using a mixture of solvents is more efficient than oil extraction. This is in agreement with the present study. Also it was observed that for any dry sample (deproteinized or non deproteinized), $90 \%$ acetone was found to be the best solvent for carotenoid extraction.

Several reports are available on the yield of astaxanthin from different species of deep sea shrimps. Of these, highest yield of $14.8 \mathrm{mg} / 100 \mathrm{~g}$ dry waste was reported by Shahidi and Synowiecki [25] from the waste of $P$. borealis shrimp. In the present study we obtained an yield of $87.14 \mu \mathrm{g} / \mathrm{g}$ wet waste from Aristeus alcocki. This is equivalent to 25.44 $\mathrm{mg} / 100 \mathrm{~g}$, on dry waste. The present study thus reveals that, of the different species of deep sea shrimps Aristeus alcocki shell waste is an excellent source of astaxanthin.

At present $P$. borealis shrimp waste is commercially exploited for the production of natural astaxanthin $(\mathrm{M} / \mathrm{s}$ Bioprawns, Norway). Since astaxanthin content in Aristeus alcocki shell waste is double the content of astaxanthin in $P$. borealis there is ample scope for exploiting Aristeus alcocki

Table 4. Extraction Yields of Carotenoids in Different Solvents and Vegetable Oils

\begin{tabular}{|c|c|c|c|c|c|c|c|}
\hline $\begin{array}{l}\text { Extraction } \\
\text { Media } \\
\text { material }\end{array}$ & 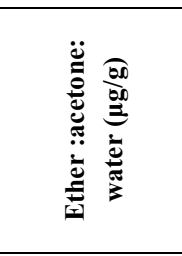 & 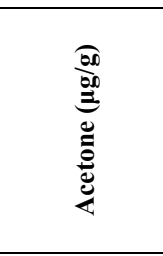 & 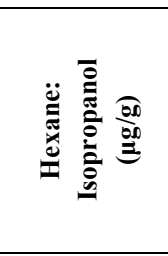 & 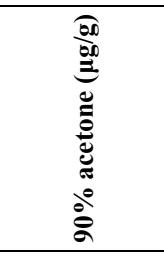 & 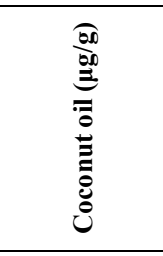 & 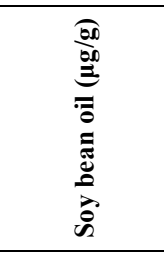 & 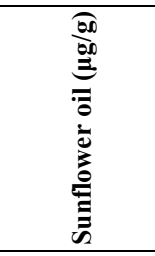 \\
\hline Dry(D) & $21.25 \pm 0.86^{\mathrm{a}, \mathrm{g}}$ & $15.74 \pm 0.83^{\mathrm{b}, \mathrm{g}}$ & $20.34 \pm 0.35^{\mathrm{c}, \mathrm{g}}$ & $22.79 \pm 1.33^{\mathrm{d}, \mathrm{g}}$ & $3.32 \pm 0.23^{\mathrm{c}, \mathrm{g}}$ & $1.36 \pm 0.15^{\mathrm{f}, \mathrm{g}}$ & $1.48 \pm 0.20^{\mathrm{f}, \mathrm{g}}$ \\
\hline EDD & $0.47 \pm 0.86^{\mathrm{a}, \mathrm{h}}$ & $1.15 \pm 0.19^{\mathrm{a}, \mathrm{h}}$ & $0.29 \pm 0.05^{\mathrm{a}, \mathrm{h}}$ & $1.17 \pm 0.13^{\mathrm{a}, \mathrm{h}}$ & ND & $0.65 \pm 0.30^{\mathrm{a}, \mathrm{c}, \mathrm{g}}$ & $0.43 \pm 0.04^{\mathrm{c}, \mathrm{h}}$ \\
\hline $\mathrm{ADD}$ & $0.36 \pm 0.04^{\mathrm{a}, \mathrm{h}}$ & $0.74 \pm 0.08^{a . h}$ & $0.19 \pm 0.06^{\mathrm{a}, \mathrm{h}}$ & $0.75 \pm 1.00^{\mathrm{a}, \mathrm{h}}$ & $0.22 \pm 0.03^{\mathrm{a}, \mathrm{h}}$ & $0.31 \pm 0.02^{\mathrm{a}, \mathrm{h}}$ & $0.37 \pm 0.07^{\mathrm{a}, \mathrm{h}}$ \\
\hline Wet(W) & $40.22 \pm 1.15^{\mathrm{a}, \mathrm{i}}$ & $87.14 \pm 4.55^{\mathrm{b}, \mathrm{i}}$ & $70.27 \pm 2.58^{\mathrm{c}, \mathrm{i}}$ & $41.46 \pm 2.51^{\mathrm{d}, \mathrm{i}}$ & $23.05 \pm 2.09^{\mathrm{e}, \mathrm{i}}$ & $20.27 \pm 0.88^{\mathrm{f}, \mathrm{i}}$ & $18.06 \pm 0.82^{\mathrm{g}, \mathrm{i}}$ \\
\hline EDW & $10.56 \pm 0.23^{\mathrm{a} . \mathrm{j}}$ & $21.43 \pm 1.33^{\mathrm{b}, \mathrm{j}}$ & $12.04 \pm 0.99^{b, j}$ & $1.10 \pm 0.18^{\mathrm{c}, \mathrm{h}}$ & $5.07 \pm 0.17^{\mathrm{d}, \mathrm{j}}$ & $3.79 \pm 0.39^{\mathrm{e}, \mathrm{j}}$ & $4.01 \pm 0.61^{\mathrm{f}, \mathrm{j}}$ \\
\hline ADW & $9.70 \pm 0.75^{\mathrm{a}, \mathrm{k}}$ & $17.38 \pm 0.59^{\mathrm{b}, \mathrm{k}}$ & $9.84 \pm 0.72^{\mathrm{b}, \mathrm{k}}$ & $1.36 \pm 0.31^{\mathrm{c}, \mathrm{h}}$ & $4.51 \pm 0.36^{\mathrm{d}, \mathrm{j}}$ & $2.88 \pm 0.13^{\mathrm{d}, \mathrm{k}}$ & $2.40 \pm 0.21^{\mathrm{e}, \mathrm{k}}$ \\
\hline
\end{tabular}

Values are mean \pm SD of four different estimations. Values having the same superscript in the same column and same row are not significantly different at $5 \%$ level.

D - Dry non deproteinized sample W - Wet non deproteinized sample.

EDD - Enzyme deproteinized dry sample

EDW - Enzyme deproteinized wet sample.

ADD - Alkali deproteinized dry sample

ADW - Alkali deproteinized wet sample. 
shell waste for the commercial production of natural astaxanthin.

\subsection{Determination of Different Components in Shrimp Shell Waste Extract by Thin Layer Chromatography}

Thin layer chromatographic separation of carotenoid extracts from Aristeus alcocki yielded three distinct bands (Table 5). The $\mathrm{R}_{\mathrm{f}}$ values for the three bands were respectively $0.33,0.60,0.78$ which corresponded to astaxanthin, astaxanthin monoester, astaxanthin diester. The $\mathrm{R}_{\mathrm{f}}$ values obtained for astaxanthin monoester and astaxanthin diester are in agreement with the results reported by Kobayashi and Sakamoto [29], 0.60 for astaxanthin monoester and 0.75-0.85 for astaxanthin diester. The $R_{f}$ value of astaxanthin obtained in the present study is in accordance with the $R_{f}$ value obtained for the standard astaxanthin and also the $R_{f}$ value reported by Todd [40]. Spectrophotometric quantification of three bands showed that the extract contained astaxanthin: astaxanthin monoester: astaxanthin diester in the ratio 1:1:2 showing the predominance of astaxanthin diester.

Sahidi et al. [3] and Sachindra et al. [5] have reported that astaxanthin and its esters are the major carotenoids in the marine crustaceans. Breithaupt [41] observed that homogenous diester astaxanthin was the predominant compound, followed by mixed diester astaxanthin in the carotenoid extract from Pandalus borealis. Sachindra et al. [42] reported that astaxanthin and its mono and diesters (63.5-92.2\%) were the major carotenoids in Aristeus alcocki and Solonocera indica, two important deep sea species from Indian waters. A quantitative study of carotenoid distribution in those species have revealed a higher proportion of esterified astaxanthin than the free form. A. alcocki had a higher proportion of astaxanthin esters (61.7-70.8\%) compared to $S$. indica $(43.8-58.4 \%)$.

Table 5. $\mathbf{R}_{\mathrm{f}}$ Value of Different Carotenoids in the Extract from Aristeus alcocki, (Mean of Three Determinations)

\begin{tabular}{|c|c|}
\hline Carotenoid & $\mathbf{R}_{\mathbf{f}}$ value \\
\hline \hline Astaxanthin diester & 0.78 \\
\hline Astaxanthin monoester & 0.60 \\
\hline Astaxanthin & 0.33 \\
\hline
\end{tabular}

\subsection{Fatty Acid Composition in Astaxanthin Monoester and Astaxanthin Diester}

The fatty acid composition in astaxanthin monoester and astaxanthin diester are presented in Tables $\mathbf{6}$ and 7, respectively. Astaxanthin monoester contained $49.29 \%$ saturated fatty acids, $30.43 \%$ monounsaturated fatty acids and $20.28 \%$ polyunsaturated fatty acids (PUFAs). Astaxanthin diester contained $41.94 \%$ saturated fatty acids, $29.91 \%$ monounsaturated fatty acids and $29.85 \%$ PUFAs. In the case of monoester, the main fatty acids esterified with astaxanthin were palmitic acid $(18.38 \%)$ and oleic acid $(14.40 \%)$. The main PUFAs present in the monoester were eicosapentaenoic acid (EPA, 20:5, $\omega-3)$ (4.83\%) and docosahexaenoic acid (DHA, 22:6, $\omega-3)(6.58 \%)$. In the case of diester, the main fatty acids esterified with astaxanthin were palmitic acid (20.47\%), oleic acid (18.19\%) and PUFAs: EPA (8.79\%) and DHA (11.36\%).

The fatty acid profiles are in agreement with the findings of Maoka and Akimoto [11], who reported that saturated fatty acids constitute $45.55 \%$, monounsaturated fatty acids constitute $30.25 \%$ and PUFAs $29.3 \%$ in the two monoester fractions of spiny lobster Panulirus japonicus. Whereas in astaxanthin diester saturated fatty acids, monounsaturated fatty acids and PUFAs constituted $47.95 \%, 22.80 \%$ and $22.95 \%$ respectively. Crustaceans accumulate carotenoid in both free and esterified forms and esterification increased the stability of carotenoid in the lipid matrix. Maoka and Akimoto [11] reported that $66 \%$ of carotenoids were esterified in spiny lobster Panulirus japonicus. The major fatty acids esterified with astaxanthin were identified as stearic acid, oleic acid and palmitoelic acid followed by PUFAs such as docosahexaenoic acid (DHA), eicosapentaenoic acid (EPA). Similar results were obtained in the present study with palmitic acid, oleic acid and stearic acid being the major fatty acids in mono and diester followed by PUFAs, DHA and EPA. Sachindra et al. [42] reported that unsaturated fatty acid constituted $60.5 \%$ of the carotenoid extract from the head of A. alcocki, while saturated fatty acids $(83.5 \%)$ were predominant in the carotenoid extract from the carapace of $S$. indica. The present study thus reveals that the carotenoid extract from Aristeus alcocki shell waste is mainly composed of free astaxanthin, astaxanthin monoester and astaxanthin diester in the proportion 1:1:2. The fatty acid composition of the monoester reveals that saturated fatty acids, MUFA and PUFA are in the ratio 5:3:2 whereas in diester they are in the ratio $4: 3: 3$.

Table 6. Fatty Acid Composition of Astaxanthin Monoester, as Per Cent of Fatty Acid

\begin{tabular}{|c|c|c|}
\hline Sl. No. & Component & Area \% \\
\hline 1 & $\mathrm{C} 12$ & 3.002 \\
\hline 2 & $\mathrm{C} 14$ & 4.161 \\
\hline 3 & $\mathrm{C} 16$ & 18.382 \\
\hline 4 & C16:1 & 2.930 \\
\hline 5 & $\mathrm{C} 17$ & 0.910 \\
\hline 6 & $\mathrm{C} 18$ & 9.281 \\
\hline 7 & C18:1 & 14.400 \\
\hline 8 & C18:2 & 1.236 \\
\hline 9 & $\mathrm{C} 18: 3$ & 1.867 \\
\hline 10 & C20:1 & 8.468 \\
\hline 11 & C20:4 & 2.844 \\
\hline 12 & $\mathrm{C} 20: 3 \& \mathrm{C} 21$ & 2.922 \\
\hline 13 & C20:5 & 4.832 \\
\hline 14 & $\mathrm{C} 22$ & 7.388 \\
\hline 15 & C22:1 & 1.758 \\
\hline 16 & C22:6 & 6.577 \\
\hline 17 & $\mathrm{C} 24$ & 6.165 \\
\hline 18 & $\mathrm{C} 24: 1$ & 2.878 \\
\hline
\end{tabular}


Table 8. In Vitro Antioxidant Activity of Astaxanthin from Shrimp Shell Waste (Aristeus alcocki), $\mathrm{IC}_{50}, \mathrm{n}=6$

\begin{tabular}{|c|c|c|c|}
\hline Activity & Astaxanthin $($ Mean \pm SD) & Quercetin $($ Mean \pm SD) & Catechin $($ Mean \pm SD) \\
\hline \hline Superoxide radical scavenging activity & $27.91 \pm 0.54 \mathrm{ng} / \mathrm{ml}$ & $41.21 \pm 0.76 \mu \mathrm{g} / \mathrm{ml}$ & - \\
\hline Inhibition of lipid peroxidation & $26.54 \pm 0.42 \mathrm{ng} / \mathrm{ml}$ & - & $432 \pm 10.2 \mu \mathrm{g} / \mathrm{ml}$ \\
\hline Hydroxyl radical scavenging activity & $56.43 \pm 1.06 \mathrm{ng} / \mathrm{ml}$ & - & $842 \pm 16 \mu \mathrm{g} / \mathrm{ml}$ \\
\hline
\end{tabular}

Table 7. Fatty Acid Composition of Astaxanthin Diester, as Per Cent of Fatty Acid

\begin{tabular}{|c|c|c|}
\hline Sl. No. & Component & Area \% \\
\hline \hline 1 & $\mathrm{C} 14$ & 2.121 \\
\hline 2 & $\mathrm{C} 16$ & 20.472 \\
\hline 3 & $\mathrm{C} 16: 1$ & 4.249 \\
\hline 4 & $\mathrm{C} 17$ & 0.947 \\
\hline 5 & $\mathrm{C} 18$ & 8.800 \\
\hline 6 & $\mathrm{C} 18: 1$ & 18.197 \\
\hline 7 & $\mathrm{C} 18: 2$ & 2.232 \\
\hline 8 & $\mathrm{C} 18: 3$ & 1.116 \\
\hline 9 & $\mathrm{C} 20: 1$ & 6.333 \\
\hline 10 & $\mathrm{C} 20: 4$ & 3.988 \\
\hline 11 & $\mathrm{C} 20: 3 \& \mathrm{C} 21$ & 1.690 \\
\hline 12 & $\mathrm{C} 20: 5$ & 8.797 \\
\hline 13 & $\mathrm{C} 22$ & 3.201 \\
\hline 14 & $\mathrm{C} 22: 2$ & 0.665 \\
\hline 15 & $\mathrm{C} 22: 6$ & 11.360 \\
\hline 16 & $\mathrm{C} 24$ & 4.708 \\
\hline 17 & $\mathrm{C} 24: 1$ & 1.125 \\
\hline
\end{tabular}

\subsection{Antioxidant Activity}

Astaxanthin extracted from shell waste of Aristeus alcocki possessed significant hydroxyl radical scavenging activity, lipid peroxidation-inhibiting activities and superoxide radical-scavenging activity (Table 8). The extract showed $50 \%$ inhibition $(50 \%$ inhibiting concentration) at concentrations $56.43 \pm 1.06 \mathrm{ng} / \mathrm{ml}, 26.54 \pm 0.42 \mathrm{ng} / \mathrm{ml}$, $27.91 \pm 0.54 \mathrm{ng} / \mathrm{ml}$. The standard antioxidants quercetin and catechin showed antioxidant activity at microgram levels whereas astaxanthin present in shrimp shell extract showed in vitro antioxidant activity at nanogram levels. This clearly indicates the high antioxidant potential of astaxanthin extracted from Aristeus alcocki shell waste.

Bell et al. [43] in a feeding study with salmon showed that the antioxidant synergism of vitamin $\mathrm{E}$ and astaxanthin reduced malondialdehyde formation in an in vitro stimulation of microsomal lipid peroxidation. Oxygen derived free radicals or reactive oxygen species (ROS) formed in the body during energy producing metabolic process, play an important role in pathophysiology of a number of diseases [44]. Normally oxygen free radicals are neutralised by natural antioxidants. However, ROS become a problem when either a decrease in their removal or their overproduction occurs, resulting in oxidative stress. This stress and the resultant damage have been implicated in many diseases and a wealth of preventive drugs and treatments are currently being studied. Thus, astaxanthin exhibiting multiple antioxidant activity will find utility in applications like antioxidant therapy, which is based on reducing oxidative stress in the target tissues. Since synthetic astaxanthin is a mixture of three stereoisomers $(3 R, 3$ 'R; $3 S$ 3'S; 3R,3'S) astaxanthin from natural sources is preferred for using it as an antioxidant. Astaxanthin from natural sources is abundant in the isomer showing highest biological activity (3R,3'R; 3S 3'S).

Kamath et al. [45] has reported that the $\mathrm{IC}_{50}$ values for free radical scavenging activity of Haematococcus pluvialis astaxanthin esters in vitro were $8.0 \mu \mathrm{g} / \mathrm{ml}$. In the present study the in vitro $\mathrm{IC}_{50}$ values reported for antioxidant activity of astaxanthin from Aristeus alcocki shell waste are in the range of $\mathrm{ng} / \mathrm{ml}$. This clearly indicates the astaxanthin extract from Aristeus alcocki is a more powerful antioxidant than the astaxanthin esters present in the Haematococcus pluvialis. This may be due to a higher proportion of astaxanthin diester and a higher content of poly unsaturated fatty acids (20\% PUFAs in monoester and $30 \%$ PUFAs in diester) in the carotenoid extract obtained from Aristeus alcocki shell. Thus, the powerful antioxidant property of carotenoid extract of Aristeus alcocki may be attributed to the antioxidant synergism of astaxanthin and poly unsaturated fatty acids (PUFAs) present in the extract.

\subsection{Antiinflammatory Activity}

Carotenoid extract from Aristeus alcocki significantly inhibited the acute inflammation induced by carageenan. Analysis of variance for increase in paw thickness of Balb/c mice with different treatments showed that the extract from shrimp shell waste significantly reduced carageenan induced paw edema. The reduction in edema was noted in a dose dependent manner (Table 9). Astaxanthin concentrations at $0.5 \mathrm{mg} / \mathrm{kg}$ body weight and $1.0 \mathrm{mg} / \mathrm{kg}$ body weight inhibited the inflammation by 47.83 and 67.11 percent (Table 9). The inhibition of inflammation at $1.0 \mathrm{mg} / \mathrm{kg}$ body weight was greater than the standard reference drug diclofenac.

Results of the present investigations reveal that astaxanthin exhibited significant dose dependent antiinflammatory activity in acute inflammations, within mice in a dose dependent manner. This confirms the findings of previous studies. Ohgami et al. [46] demonstrated a dose dependent anti-inflammatory effect of astaxanthin by supression of nitric oxide (NO), prostaglandin E2 (PGE2) and tumour necrosis factor (TNF- $\alpha$ ) production by directly blocking nitric oxide synthase (NOS) enzyme activity. Kurashige et al. [47] also reported that carrageenan induced swelling of the paw of rats fed with astaxanthin was 
Table 9. Effect of Astaxanthin Extract on Carageenan Induced Paw Edema

\begin{tabular}{|c|c|c|c|c|}
\hline Treatment & Initial paw thickness $(\mathbf{m m})$ & Paw thickness on 3 h $(\mathbf{m m})$ & Increase in paw thickness $(\mathbf{m m})$ & \% inhibition \\
\hline \hline Control & $15.00 \pm 0.09$ & $25.37 \pm 0.31$ & $10.37 \pm 0.13^{\mathrm{a}}$ & - \\
\hline Standard (Diclofenac) & $15.66 \pm 0.08$ & $20.54 \pm 0.24$ & $5.88 \pm 0.26^{\mathrm{b}}$ & 52.94 \\
\hline $\begin{array}{c}0.5 \mathrm{mg} \text { astaxanthin/kg body } \\
\text { weight }\end{array}$ & $15.55 \pm 0.11$ & $20.96 \pm 0.29$ & $3.18^{\mathrm{c}}$ & 67.83 \\
\hline $\begin{array}{c}\text { 1.0mg astaxanthin } \\
\text { /kg body weight }\end{array}$ & $15.76 \pm 0.09$ & $19.17 \pm 0.14$ & 67.11 \\
\hline
\end{tabular}

Values expressed as mean \pm S.D, $n=6$ animals, Values having the same superscript in same column are not significantly different at $5 \%$ level.

significantly lower than that of control. This explains the anti-inflammatory role of astaxanthin. Bennedsen et al. [48] and Wang et al. [49] reported that dietary astaxanthin was found to help fight symptoms of ulcer disease from Helicobacter pylori which causes inflammation of gastric tissues. Kim et al. [50] reported that astaxanthin is effective in protection against gastric lesions induced by the use of non steroid anti-inflammatory drugs such as naxopen. Mahmoud et al. [51] reported that suppression of T-cell activation makes astaxanthin as effective as commonly used antihistamines and hence may have a role in novel antiasthmatic formulations.

Astaxanthin has been studied extensively due to its superior antioxidant and anti-inflammatory properties. The present study demonstrates that natural astaxanthin from Aristeus alcocki shrimp waste inhibits carrageenan induced inflammatory response in mice. This anti-inflammatory effects of astaxanthin from Aristeus alcocki shell has important implications for the development of antiinflammatory drugs from shrimp shell waste.

\section{CONCLUSION}

The Industrial shrimp shell discards can be utilized for the isolation of important bioactive compounds like natural carotenoids, mainly astaxanthin. Of the different extraction media and samples tried maximum yield of carotenoids was obtained with non deproteinized wet waste using acetone. Thin layer chromatographic separation showed that the carotenoid extract from Aristeus alcocki shell discard contained astaxanthin, astaxanthin mono and diesters in the proportion of 1:1:2. The monoester and diester contained saturated fatty acids, MUFA and PUFAs in the ratio 5:3:2 and $4: 3: 3$, respectively. The main fatty acids esterified with astaxanthin were palmitic acid, oleic acid and $\omega-3$ PUFAs especially EPA and DHA. The carotenoid extract exhibited significant antioxidant and anti-inflammatory activities. This might be due to the combined action of astaxanthin and $\omega-3$ PUFAs present in the astaxanthin esters of the extract. Natural astaxanthin and its $\omega-3$ PUFA esters in shrimp shell discards may find application in the pharmaceutical industry for the treatment and/ or prevention of pathological conditions induced by oxidative stress.

\section{ACKNOWLEDGEMENTS}

The first author wishes to thank Kerala Agricultural University for awarding a merit scholarship during the tenure of the work.

\section{REFERENCES}

[1] Barratt, A.; Montano, R. Shrimp heads-a new source of protein. INFOFISH Markg. Dig., 1986, 4(86), 21.

[2] Shahidi, F.; Synowiecki, J.; Naczk, M. In Seafood Science and Technology; Bligh, E.G. Ed.; Fishing News Books, 1992; pp. 301304

[3] Shahidi, F.; Metusalach; Brown, J.A., Carotenoid pigments in seafoods and aquaculture. CRC Crit. Rev. Food Sci., 1998, 38, 167.

[4] Venugopal, V. Marine Products for Healthcare: Functional and Bioactive Neutraceutical Compounds from the Ocean. CRC Pess, New York, 2008

[5] Sachindra, N.M.; Bhaskar, N.; Mahendrakar, N.S. Carotenoids in different body components of Indian shrimps. J. Sci. Food Agric., 2005a, $85,167-172$.

[6] Sachindra, N.M.; Bhaskar, N.; Sakhare, P.Z.,; Mahendrakar, N.S.; Narasimha Rao, D. An improved process for recovery of carotenoids from crustacean waste. Indian Patent 95/DEL/2001, 31 January, 2001.

[7] Sachindra, N.M.; Bhaskar, N.; Mahendrakar, N.S. Recovery of carotenoids from shrimp waste in organic solvents. Waste Manage., 2006a, 26, 1092-1098.

[8] Li, H.; Tyndale, S.J.; Heath, D.D.; Letcher, R.J. Determination of carotenoids and all-trans-retinol in fish eggs by liquid chromatographyelectrospray ionization-tandem mass spectrometry. J. Chromatogr., 2005, 816, 49-56.

[9] Sachindra,N.M.; Bhaskar, N.; Mahendrakar, N.S. Carotenoids in crabs from marine and fresh waters of India. Lebensm. Wiss. Technol., 2005b, 38, 221-225.

[10] Lopez-Cervantes, J., Sanchez-Mahado, D.I., Gutierrez-Coronado, M.A. and Rios-Vazquez, N.J. Quantification of astaxanthine in shrimp waste hydrolysate by HPLC. Biomed. Chromatogr., 2006, 20, 981-984.

[11] Maoka, T.; Akimoto, N. Carotenoids and their fattyacid esters of spiny lobster Panulirus japonicus. J. Oleo. Sci., 2008, 57(3), 145152.

[12] Quan, C.; Turner, C. Extraction of astaxanthin from shrimp waste using pressurized hot ethanol. Chromatographia, 2009, 70(1-2), 247-251.

[13] Anderson, L.K. Extraction of carotenoid pigment from shrimp processing waste. US Patent 3,906,112, 1975.

[14] Torrisen, O.J.; Tideman, E.; Hansen, F.; Raa, J. Ensilaging in acid - a method to stabilize astaxanthin in shrimp processing byproducts and improve uptake of this pigment by rainbow trout (Salmo gairdneri). Aquaculture, 1981, 26, 77-83.

[15] Chen, H.; Meyers, S.P. Extraction of astaxanthin pigment from Crawfish waste using a soy oil process. J. Food Sci., 1982, 47(3), 892-896

[16] Chen, H.; Meyers, S.P. Ensilage treatment of crawfish wastefor improvement of Astaxanthin pigment extraction. J. Food Sci., 1983, 48(5), 1516-1520.

[17] Chen, H.M.; Meyers, S.P.; A rapid quantitative determination of astaxanthin pigment concentrate in oil extraction. J. Am. Oil. Chem. Soc., 1984, 61, 1045-1047.

[18] Sachindra, N.M. and Mahendrakar, N.S. Process optimization for extraction of carotenoids from shrimp waste with vegetable oils. Bioresource. Technol., 2005, 96, 1195-1200. 
[19] Holanda, H.D.D.; Netto, F.M. Recovery of components from shrimp (Xiphopenaeus kroyeri) processing waste by enzymatic hydrolysis. J. Food Sci., 2006, 71(5), 298-303.

[20] Handayani, A.D.; Sutrisno., Indraswati, N.; Ismadji, S. Extraction of astaxanthin from giant tiger (Panaeus monodon) shrimp waste using palm oil: Studies of extraction kinetics and thermodynamics. Bioresour. Technol., 2008, $99(10), 4414-4419$.

[21] Khanfari, A.; Saberi, A.; Azar, M.; Vosooghi, Gh.; Jamili, Sh.; Sabbaghzadeh, B. Extraction of astaxanthin esters from shrimp waste by chemicaland microbial methods. Iranian. J. Environ. Health Sci. Eng., 2007, 4(2), 93-98.

[22] A.O.A.C. Official Methods of Analysis. $15^{\text {th }}$ ed. Association of Official Analytical Chemists, Washington, 1990.

[23] Spinelli, J.; Lehman, L.; Wieg, D. Composition, processing, and utilization of red crab (Pleuroncodes planipes) as an aquacultural feed ingredient. J. Fish. Res. Board Can., 1974, 31, 1025-1029.

[24] Synowiecki, J.; Al-Khateeb, N.A. The recovery of protein hydrolysate during enzymatic isolation of chitin from shrimp Crangon crangon processing waste discards. Food Chem., 2000, 68, 147-152.

[25] Shahidi, F.;Synowieki, J. Isolation and characterisation of nutrients and value added products from snow crab (Chinoecetes opilio) and shrimp (Pandalus borealis) processing discards. J. Agric. Food Chem., 1991, 39, 1527-1532.

[26] Barbosa, M.J.; Morais, R.; Choubert, G. Effect of carotenoid source and dietary lipid content on blood astaxanthin concentration in rainbow trout (Oncorhychus mykiss). Aquaculture 1999, 176, 331334.

[27] Kobayashi, M.; Kurimura, Y.; Sakamoto, Y.; Tsuji, Y. Selective extraction of astaxanthin and chlorophyll from the green alga Haematococcus pluvialis. Biotech. Tech., 1997, 11(9), 657-660.

[28] Kelley, C.E.; Harmon, A.W. Method of determining carotenoid contents of Alaska pink shrimp and representative values for several shrimp products. Fish. Bull., 1972, 70, 11-17.

[29] Kobayashi, M.; Sakamoto, Y. Singlet oxygen quenching ability of astaxanthin esters from the green alga Haematococcus pluvialis. Biotechnol. Lett., 1999, 21, 265-269.

[30] Metcalfe, L.D.; Schimitz, A.A.; Ratta, J.R. Rapid preparation of fatty acid esters from lipids for chromatograph analysis. Anal. Chem., 1966, 38, 514-519.

[31] McCord, J.M.; Fridovich, I. Superoxide dismutase and enzymatic function of erythrocuprein. J. Biol. Chem, 1969, 244, 6049-6055.

[32] Ohkawa, H.; Ohishi, N.; Yagi, K. Assay for lipid peroxides in animal tissues by thiobarbituric acid reaction. Anal. Biochem., 1979, 95351-95358

[33] Elizabeth, K.; Rao, M.N.A. Oxygen radical scavenging activity of curcumin. Int. J. Pharmacol., 1990, 58, 237-240.

[34] Ajith, T.A.; Janardhanan, K.K. Antioxidant and anti-inflammatory activities of methanolic extract of Phellinus rimosus (Berk). Indian. J. Exp. Biol., 2001, 39, 1166-1169.

[35] Nair, K.G.R.; Madhavan, P.; Gopakumar, K. In: Textbook of Fish Processing Technology, Indian Council of Agricultural Research, New Delhi, 2002, pp. 467-483.

[36] Madhavan, P.; Nair, K.G.R. Chitosan from squilla. Fish. Technol., 1975, 12, 81-82.

[37] Cianci, M.; Rizkallah, P. J.; Olczak, J.; Raftery, N.E.; Chayen, N.E.; Zagalsky, P.F.; Helliwell, J. R. Structure of lobster apocrstacyanin A1 using softer X-rays. Acta.Crystallogr., 2001, 57, 1219-1229.

[38] Vimala, S.; Paul, V.I. Utilization of crustacean fishery waste as a source of carotenoids. J. Exp. Zool. Ind., 2009, 12(2), 377-380.

[39] Delgrado-Vargus, F.; Jimenez, A.R.; Peredes-Lopez, O. Natural pigments: carotenoids, anthocyanins and betalains: characteristics, biosynthesis, preparation and stability. CRC Crit. Rev. Food. Sci. Nutr., 2000, 40, 173-289.

[40] Todd, L. Thin layer chromatography (TLC) system for Natu Rose Cartenoids. Natu Rose. Technol. Bull., 1998, 003, 1-3.

[41] Breithaupt, D.E. Identification and quatification of astaxanthin esters in shrimp (Pandalus borealis) and in microalga (Haematococcus pluvialis) by liquid chromatography-mass spectrometry using negative ion atmospheric pressure chemical ionization. J. Agric. Food Chem., 2004, 52, 3870-3875.

[42] Sachindra, N.M.; Bhaskar, N.; Mahendrakar, N.S. Carotenoids in Solonocera indica and Aristeus alcocki, deep-sea shrimp from Indian waters. J. Aqua. Food Prod. Technol., 2006b. 15(2), 5-16.

[43] Bell, J.G.; McEvoy, J.; Tocher, D.R.; Sargent, J.R. Depletion of alpha-tocopherol and astaxanthin in Atlantic salmon, (Salmo salar) affects autoxidative defense and fatty acid metabolism. J. Nutr., 2000, 130(7), 1800-1808.

[44] Cuzzocrea, S.; Riley, D.P.; Caputi, A.P.; Salvemini, D. Antioxidant therapy: A new pharmacological approach in shock, inflammation and ischemia/ reperfusion injury. Pharmacol. Rev., 2001, 539, 139159.

[45] Kamath, B.S.; Srikanta, B.M.; Dharmesh, S.M.; Sarada, R.; Ravishankar G.A. Ulcer preventive and antioxidant properties of astaxanthin from Hematococcus pluvialis. Eur. J. Pharmacol., 2008, 590(1-3), 387-395.

[46] Oghami, K.; Shiratori, K.; Kotake, S.; Nishida, T.; Mizuki, N.; Yazawa, K..;Olino, S. Effects of astaxanthin on lipopolysaccharideinduced inflammation in vitro and in vivo. Invest. Ophthalmol. Vis. Sci., 2003, 44(6), 269-2701.

[47] Kurashige, M.; Okimasu, E.; Inoue, M.; Utsumi., K.. Inhibition of oxidative injury of biological membranes by astaxanthin. Physiol. Chem. Phys. Med. NMR., 1990, 22, 27-38.

[48] Bennedsen, M.; Wang, X.; Willen, R.; Wadstrom, T.; Andersen, L.P. Treatment of H. pylori infected mice with antioxidant astaxanthin reduces gastric inflammation, bacterial load and modulates cytokine release by splenocytes. Immunol. Lett., 1999, 70, 185-189.

[49] Wang, W.H.; Geibel, J.; Giebisch, G. Mechanism of apical K+ channel modulation in principal renal tubule cells. Effect of inhibition of basolateral Na+ - K+ ATPase, J. Gen. Phys., 1993, 101, 673-694.

[50] Kim, J.H.; Kim, Y.S.; Song, G.G.; Park, J.J.; Chang, H.I. Protective effects of astaxanthin on naxopen-induced gastric antral ulceration in rats. Eur. J. Pharmacol., 2005, 514 (1), 53-59.

[51] Mahmoud, F.F.; Haines, D.D.; Abul, H.T.; Abal, A.T.; Onadeko, B.O.; Wise, J.A.. In vitro effects of astaxanthin combined with ginkgolide $\mathrm{B}$ on $\mathrm{T}$ lymphocyte activation in peripheral blood mononuclear cells from asthmatic subjects. J.Pharmacol. Sci., 2004, 94, 129-136.

(C) Sindhu and Sherief; Licensee Bentham Open.

This is an open access article licensed under the terms of the Creative Commons Attribution Non-Commercial License (http://creativecommons.org/licenses/by-nc/3.0/) which permits unrestricted, non-commercial use, distribution and reproduction in any medium, provided the work is properly cited. 